\title{
Sustainable disaster supply chain management for relief operations in Bangladesh
}

\author{
Zerin Tasnim \\ Faculty, Southeast Business School, Southeast University, Bangladesh \\ zerinarna03@gmail.com
}

\author{
Abu Bakar A. Hamid \\ Professor, Putra Business School, University Putra Malaya, Malaysia \\ abu.bakar@putrabs.edu.my
}

Yogesh K Dwivedi a, b
aEmerging Markets Research Centre (EMaRC), School of Management, Room \#323
Swansea University, Bay Campus, Fabian Bay, Swansea, SA1 8EN, Wales, UK
Email: y.k.dwivedi@swansea.ac.uk

bymbiosis Institute of Business Management, Pune \& Symbiosis International (Deemed

University), Pune, India

\author{
Mahmud A. Shareef \\ Professor, North South University, Bangladesh \\ mahmud_akh@yahoo.com
}

\begin{abstract}
Purpose- Number of disastrous events are rising globally and it's an immense important to manage the humanitarian supply chain management process to assist the disaster affected individuals in terms of relief operations. Effective relief operations can help to recover the materialistic loss due to any disaster. But there is a paucity of studies regarding this issue for developing countries. This study hence inspected the factors that affect the disaster supply chain management processes for relief operations in Bangladesh.
\end{abstract}

Design/Methodology/approach- This study examined the factors affecting relief operations through a qualitative analysis. This study used thematic analysis. Interviews were conducted with related supply chain individuals who were triangulated by data from related publications and blogs.

Findings- The study showed that sustainable DSCM for relief operations in Bangladesh require addressing few factors as organizational capabilities, warehousing locations and inventory 
management, infrastructure facility, coordination among partners, government and local authority support to create a transparent, efficient, effective and sustainable DSCM process for relief operations in Bangladesh. The system loopholes can be identified and rectified on the base of these factors,

Research limitations/implications-The number of interview respondents was limited to twenty who were selected randomly from four organizations. To create a sustainable disaster SCM for relief operations few factors were considered as predominant factors in Bangladesh context to generalize the developing country contexts and other factors were not considered. Therefore, for farther humanitarian research, the model of this study can be used for quantitative research and the hypotheses can be tested empirically to get more acute findings.

Practical implications- As this study identifies the factors which can help to create a sustainable DSCM system for relief operations, hence practically, Bangladesh humanitarian SCM agencies will be beneficial from this study. They can easily recognize the factors need to be considered to create a sustainable DSCM process for relief operations.

Originality/value- This is a unique study carried out to examine the factors affecting DSCM process for relief operations in Bangladesh.

Keywords Humanitarian, disaster supply chain management, relief operations

Paper type Research paper

\section{Introduction}

Frequency and severity of disasters are increasing globally. Disaster usually disrupts the supply chain network (Messina et al., 2020). There is an increasing demand for disaster supply chain management as more and more disasters are occurring around us. A report released by the United Nations agency for disaster risk reduction (UNISDR) notified that within the time period of 1996 and 2015, more than 7,000 disasters occurred worldwide and around 90 percent of 1.35 million people, who had died in these disasters, are from low or middle-income countries (https://sustainabledevelopment.un.org). According to Van Wassenhove (2006) there are about 500 disasters every year, killing about 75,000 people and affecting some 200 million others. Number of devastating natural events have occurred worldwide in the last 15 years. Among those most remarkable ones were the Tsunami in Southeast Asia in 2004, Katrina in New Orleans in 2005, earthquakes in Pakistan, Haiti, Japan, Nepal in 2005, 2010, 2011, 2015 respectively, hurricane Maria in Dominica and Puerto Rico in 2017, and cyclone Idai in Africa in 2019. These events caused huge loss of lives and properties (Dwivedi et al., 2018; Kavota et al., 2020; Negi et al., 2021; Roy et al., 2020; Son et al., 2020; Yuan et al., 2021). 
Ritchie et al. (2014) highlighted that disasters affect those in poverty most heavily in low-tomiddle income countries which have less infrastructure facilities. Due to environmental degradation, increasing global warming, greenhouse gas emission, changing weather patterns, rapid growth of urbanization, deforestation, human's access in hazardous locations and more industrialization in developing countries, the number of disasters both natural and manmade is increasing. In the next 50 years, the number of disasters is likely to increase five times compared to the current situation (Dubey et al., 2016b). Hence the pressure on humanitarian organizations is rising and facing a lot of challenges (Dubey et al., 2016a). Also humanitarian operations play a crucial role as the number of disasters is increasing. Maintaining the quantity and quality of relief operations and delivering those to the right time at the right places is very necessary after the occurrence of any disaster, (Dashtpeyma et al., 2021). Also good relationships among partners, trust among them, and quality of information sharing, strong resource base and infrastructure support act strongly to shape up a sustainable SC network (Papadopoulos et al., 2017). Nagendra et al. (2020) mentioned the importance of quality of information to improve effectiveness of relief operations in disaster prone areas. Information and communication (ICT) technology play a vital role for better coordination (Dwivedi et al., 2022a; He et al., 2022).

There are many prior studies focusing on various aspects of supply chain management such as risk management, technology, fleet management, communication, transportation, planning and controlling and coordination. The studies were mainly focused on the commercial supply chain. Despite having rising demand, there is lack of studies in disaster supply chain management (DSCM) context (Damoah et al., 2021) Moreover, all elements of commercial supply chain and disaster supply chain are not similar and humanitarian and disaster supply chain management has lately gain much attention (Banomyong et al., 2019; Botchie et al., 2021). Ergun et al. (2007) and Whybark (2007) pointed out a few factors to be crucial for disaster occurrence such as rapid growth of population, human access into risky areas and changing climate patterns. Despite having more technological advancement day by day, people are failing to handle the impacts of those disastrous events. Eventually the need of an improved and developed disaster supply chain management for immediate relief operations and rehabilitation are getting importance. Hence DSCM is a key area for academicians and industry practitioners to focus on and to provide organized and effective relief operations (Banomyong et al., 2019).

There are many articles concerning disaster supply chain management (DSCM) so far. However, few of them were about relief operations especially in developing countries (Polater, 2020; Chari et al., 2020). Mostly focused factors in the sustainable DSCM process included warehousing locations and inventory management, infrastructure facility, coordination with donors and aid agencies etc. (Chari et al., 2020). This study was highlighted on DSCM in the context of relief operations and can be a resource for academicians as well as practitioners. This study explored 
the factors affecting the relief operations for DSCM by interviewing related professionals. Hence this study will provide guidance to find out the crucial factors for related disaster management organizations for creating a sustainable DSCM system.

Therefore, the main objective of this paper was to carry out and analyze these practical and research gaps. This study also presents a framework of sustainable disaster supply chain management process for a developing country, Bangladesh. The main aim of the study was to analyze the factors that were required to create a transparent, efficient and effective DSCM process and finally to create a sustainable DSCM process for relief operations in Bangladesh. The study explored following the research questions :

RQ1: Why are DSCM processes for relief operations in Bangladesh not transparent, efficient and effective?

RQ2: How to create a sustainable DSCM process for relief operations in Bangladesh?

To explore these research questions, twenty in-depth semi structured interviews with key respondents were conducted over phone. They were randomly chosen from four humanitarian related organizations. Based on these findings and all pieces of information from previous studies, a conceptual framework was created. The details of the framework will help to understand that sustainable disaster supply chain management needs to focus on few factors such as organizational capabilities, communication among partners, inventory management process, government and local authority support which eventually lead to transparent, efficient and effective SCM process. A good fit among all these dimensions lead to create a sustainable DSCM process.

The rest of the paper is structured as follows: theoretical background on disaster management in Bangladesh context and few factors as organizational capabilities, communication among partners, inventory management process, government and local authority support has been provided. In the methodology section, the details of data collection, interviews and analysis process were provided and then presented the results and discussion. The following sections include recommendations, managerial and research implications. The paper was concluded by providing limitations and recommendations for further research.

\section{Disaster management in Bangladesh context}

Bangladesh is a disaster prone country due to the geographical location and climate pattern of this area. It's a developing country and the majority of people in this country is in poverty level 
(Shareef et al., 2019). Especially, the southern parts of Bangladesh are especially hit by tidal bore or devastating cyclones. This kind of disaster needs immediate rescue and relief operations. Moreover, as a developing country Bangladesh has a lack of technological support, infrastructure support and training and courses to develop skilled workers in relevant fields. Hence this country is struggling to maintain the DSCM process for relief operations effectively. Therefore, to create a sustainable disaster supply chain management for relief operations, few issues needed to be considered as support from local and international donors and relief providers, warehouse management, infrastructure facility, proper training and courses to create regional skilled workers, resource and capability of organizations, communication among partners, community participation and governmental support (Haque et al., 2013).

Disaster can be manmade or natural. But both cause devastating impact in lives and community (Dwivedi et al., 2018). The types of natural disasters occurring frequently in Bangladesh are flooding, cyclones and earthquakes. The country faced 219 separate significant natural disasters between 1980 and 2008 from earthquake, drought, riverbank erosion, tsunami, fire, hurricane and floods with resulting severe disruption to society, the economy and loss of life (Shareef et al., 2020). The low lying areas of this country face different kinds of flooding frequently that bring devastating effects on crops, livestock, property, human lives and many more. In the last fifty years more than 24 cyclones have hit Bangladesh which causes huge loss of lives and properties. Earthquake didn't cause much harm to this country yet. But due to the geographical location, this country has a high risk of a large earthquake occurrence in the near future. As a high level of population density and an unplanned infrastructure system in major cities like Dhaka may face serious disruption by a large earthquake attack in future. Bangladesh is also facing challenges due to manmade disasters such as social instability, industrial hazards and risks of pandemic. Political unrest, frequent road blockage due to accidents, garments' workers' unfulfilled demands are the main reasons for social instability. Rapid industrialization is also causing huge environmental costs (https://www.adrc.asia). Bangladesh is always at risk of pandemics due to factors like significant cross border movements, lack of quarantine stations, lack of awareness among people etc. Currently humanity is facing another pandemic, the infection of the new coronavirus known as Covid-19. Due to the worldwide lockdown situation almost all countries are facing huge trade loss (https://reliefweb.int). Though the developed countries have enough resources to handle the situation, developing countries like Bangladesh are facing a huge challenge to overcome this situation. It has already affected the economy, social lifestyle, environment, hospitality and tourism, education sector, manufacturing and service industry, aviation industry etc. Many small and medium business people have lost their livelihood and earning way. The supply chain of FMCG products is highly disrupted due to travel bans in almost all countries. Garments and textile industries in Bangladesh are at high risk now (Tasnim, 2020). 
Disaster affected communities need immediate support and relief during and after the occurrence of disaster which can be successfully handled by an effective disaster management system in developing countries (Dwivedi et al., 2018). Though the relief operations of the DSCM system of Bangladesh are working nicely, still this area has enough scope for improvement (Shareef at al., 2019). DSCM process in Bangladesh is facing challenges in terms of organizational capabilities (Alem et al., 2016), coordination and communication among employees and SC members, transparent SCM process which causes misuse of relief items from corruption, information sharing, transportation facility, distribution facility, procurement system, local authority and government support (Shareef at al., 2019) and inventory management (Alem et al., 2016). Considering previous recommendations, this study investigates the factors required for creating a sustainable DSCM process for relief operations in Bangladesh, as disaster supply chain management is still an underdeveloped sector and hence needs much attention.

\section{Theoretical background of factors for sustainable DSCM}

Following section presents theoretical background of aforementioned factors such as organizational capabilities, communication among partners, transparent SCM process, local authority and government support, inventory management and their relation with sustainable DSCM process.

\subsection{Organizational capabilities and sustainable DSCM process.}

SCM is a complex and combined network of logistics, transportation, operations Management, distribution, purchasing etc. (Tanco et al., 2018). Globalization impacts the whole SCM processes in various ways. Recently due to Covid-19 different types of SCM processes are interrupted. There are some other challenges in logistic networks for different types of disruptive situations as well (Sundarakani et al., 2020). Coleman (2006) identified that the number, frequency and nature of disaster has changed globally for the past few years. Despite the number of disasters increasing, the fatalities per incident decline in developed countries like Australia due to efficient handling of emergency situations, Shareef et al. (2019) highlighted the condition of emergency supply chain management (during and after any disaster) system of developing countries like Bangladesh needs much attention. The studies address and identify that there are loopholes in the existing disaster management system of Bangladesh and then focus on the silos that can make a supply chain effective during an emergency situation.

Alem et al., (2016) illustrated that there are some operational challenges in emergency logistics in disasters that depend on organizational capabilities including lack of reliable information of 
disaster areas, requirements of victims, type of stock, number of donors, transport facilities, lack of resources etc. For creating a resilient supply chain for disaster management, organizations must adopt multiple sourcing, holding inventories and having back up capacities to cope up with emergency situations. Organizations need to manage good relations with suppliers and other stakeholders who can help with back up resources in time of need (Zokaee et al., 2021). Coordination among all stakeholders, trust among them and their collective action increase the efficiency of DSCM processes. Also roles of technology act positively in the way to achieve sustainability (Behl et al., 2019). The implementation of advanced technologies like information technology in developing countries like India is challenging for DSCM. But technologies can have significant impact for DSCM (Tatham et al., 2015). Also advanced technologies like cloud computing have remarkable impact for managing DSC related activities (Schniederjans et al. 2016). Now DSCM is searching for new methods based on technologies like big data analytics to overcome the challenges of DSCM (Dubey et al., 2019 a,b,c).

According to Teece et al. (1997), dynamic capabilities of an organization refer to the ability to create, integrate and address both interior and exterior competencies to cope up with fast changing environments. Supply chain dynamic capabilities helps to enhance organizational flexibility and eventually help organizations to overcome any volatile situation effectively. In addition, the dynamic capability of an organization helps to solve any problem in an organized manner, helps to make accurate and timely decisions and change its resources accordingly (Barreto, 2010). Organizational dynamic capabilities (DC) play a crucial role to overcome these challenges and build up a sustainable DSCM process (Hong et al., 2018). DC is defined as integrating, building, and reconfiguring internal and external competencies to cope up with quick changing environments in terms of product development, resource allocation, knowledge creation, maintaining coordination among all partners etc. (Polater, 2020). According to Winter (2003) zero-level capabilities of an organization refer to those abilities that help an organization to survive in the short term. Whereas dynamic capabilities refer to those abilities that help an organization to extend, modify or create ordinary capabilities. Eventually an organization can gradually proceed to higher-order capabilities. Today, SCs need to be resilient enough to respond to rapid changes and to manage the flow of resources (Yu et al., 2019). Moreover the disasters are considered as predominant factors that force SCs to have higher levels of capabilities, enhance SC visibility and transparency and subsequently lead to better and sustainable operational performance. Also by improving overall dynamic capabilities, organizational efficiency and sustainability can be developed (Hong et al., 2018). Dynamic capabilities are hard for rivals to replicate because they are built on the idiosyncratic characteristics of entrepreneurial managers and are the basis of a sustainable system (Teece, 2018). 
However, all these efforts cannot be fulfilled without the necessary reconfigurations in SC strategies, resources and operational processes (Polater et al., 2020). There are potential differences between the DSCM processes between developed and developing countries like Bangladesh. DSCM processes in Bangladesh have a lack of necessary administrative support, procurement system, interoperability among organizations and also facing challenges in planning and strategy development for DSCM processes (Shareef et al., 2019). Hence this study focuses on organizational capabilities rather than dynamic capabilities for creating a sustainable DSCM process.

\subsection{Communication among partners and transparency in SCM process}

Dubey et al., (2019a) mentioned that communication and coordination among all silos of the humanitarian relief supply chain is the vital one to make a relief operation the most effective one. Alem et al., (2016) illustrated that there are some operational challenges in emergency logistics in disasters that depend on communication and coordination among supply chain partners. For a successful disaster management system it is important to share information among stakeholders at the right time. The gap in information sharing between two parties of the DSCM system causes vital problems in relief operation management (Shareef et al., 2019).

Alinaghian et al. (2020) mentioned that operation and supply chain management operations are moving their focus from single relationship with partners to collaborative pattern of relationship. Moreover, to improve disaster response, cost is a vital issue. Effective collaboration and communication with other humanitarian organizations can help to reduce cost and build up a transparent relationship (Duran et al., 2011). There are several challenges in the DSCM process including lack of coordination among partners and this is considered as crucial for the DSCM process (Ozdemir et al., 2020). Effective communication among partners will enhance system transparency (Beamon, et al., 2008).

\subsection{Transparent SCM process and sustainable DSCM process}

Communication is also necessary for effective information sharing (Beamon, et al., 2008). In developing countries like Bangladesh, availability of information at the right time is a problem in the DSCM process (Shareef et al., 2019). Moreover, effective communication builds trust to share information, have a smooth and efficient flow of products and thus reduce operational costs (Polater, 2020). In addition, effective communication leads to a transparent SC relationship. On the other hand, to build up a strong and sustainable disaster supply chain management process, organizational capacity planning and establishing a strong collaboration and coordination among SC members, both act as crucial drivers (Polater, 2020; Singh et al., 2018).

\subsection{Inventory management and SC efficiency and effectiveness}


Inventory management is an important aspect to enhance efficiency of DSC (Behlet al., 2019). According to Alem et al. (2016) a model was developed to enhance the speed and efficiency of relief operations in areas after disasters. Also this model ensures to send required reliefs and goods for any kind of disaster to happen. Facility as warehouse and distribution center location as well as number of distribution centers is also very important for quick response. Also location must be closer to disaster prone areas to reduce delivery time and warehouses must contain stock to fulfill the need of disaster victims. Inventory cost can be reduced by avoiding long time stock. Instead, some stock can be kept for emergencies and the rest demand must be fulfilled by local purchase. Although research on facility location problems is extensive, in the area of humanitarian relief, still there is paucity of studies (Beamon et al., 2008).In disaster prone areas, inventory management and stocking must be improved. In developing countries like Bangladesh, the stocking of goods are not properly managed and stored in non-dedicated warehouses which causes loss of relief items and increased lead time .Moreover lack of manpower causes delay in loading and unloading of relief item which causes increased lead time (Shareef et al., 2019).

For any sort of disasters for instances a hurricane or terrorist attack, if supplies are located closer to the disaster, it can allow for faster delivery of supplies after the disaster and hence reduce the delivery lead time and enhance SC efficiency (Bozkurt, 2011).

\subsection{Local authority \& government support and SC effectiveness and efficiency}

To build up a strong, sustainable and resilient supply chain, it's crucial to focus on the performance of post disaster phases (Polater, 2020). A sustainable and strong supply chain refers to such a system which possesses the capability to survive during disaster and can go back to the previous state after disaster (Ivanov, 2020). Disaster supply chain management process also gets interrupted by some unavoidable and unexpected issues such as poor transportation infrastructures, custom-related problems, late shipments and demand variations in relief operations. All these factors hamper the smooth relief flow (Fikar et al., 2018). Due to poor transportation facilities, the distribution of relief items gets disrupted and also lead time increases. For establishing such an effective and efficient supply chain management process, government and local authority support play predominant factors (Polater, 2020; Singh et al., 2018). Also government subsidies can help to reduce warehouse operating costs (Duran et al., 2011).

Kunz et al. (2012) analyzed various case studies of four relief organizations and mentioned that Disaster response operations aim at helping as many victims as possible in the shortest time. Moreover, Hossain (2015) has mentioned that the government of developing countries like Bangladesh has adopted disaster management plans and programs with especial emphasis on community participation and local authority support in disaster management cycle and discussed the role of social work to ensure or enhance community participation to make disaster management more effective and successful. 


\subsection{SC Efficiency \& effectiveness and sustainable DSCM process}

For disaster relief operations, three factors act as most important issues as effectiveness (quality), responsiveness (timely) and efficiency (cost effective delivery) (Charles, 2016).To improve the disaster response of a system, efficiency and effectiveness must be improved by enhancing amount of necessary inventory stock, warehouse location setup, reducing operation cost as procurement and transportation cost and by reducing response time (Duran et al., 2011). Also, to build up a sustainable DSCM process, the performance effectiveness of relief operations must be evaluated (Beamon et al., 2008).

\section{Methodology}

This chapter consists of a few subsections including sampling, methods, results and discussions. NVivo 12 software is used for coding the interview transcripts and analysis was conducted based on these coding and six themes were identified.

\subsection{Sampling and method}

There is a list of organizations enrolled under the Ministry of Disaster Management and Relief operations (Disaster Management Bureau, 2015). This study has selected four organizations from that list randomly including foreign and local organizations. All the four organizations have participated in relief operations previously. From each organization, this study has selected two to five executives (Managers or above) for Interviews considering their role in humanitarian management activities, involvement, size, and importance. This study follows qualitative methodology. In disaster supply chain management studies, inclusion of qualitative research methods is recommended by Behl et al. (2018).

A semi structured interview was conducted among employees of four such organizations. For conducting interviews, the questionnaire was developed from literature review and from a focus group discussion. The focus group was composed of ten members including five academicians and five practitioners. From the list of organizations a sample of 20 respondents was randomly selected from four humanitarian related organizations. All the respondents participated in disaster management activities for relief operations directly. Time period of each interview was 15 to 30 minutes to collect detailed answers of questions from the respondents. A total of twenty responses were collected and the interviews were conducted by the researchers. Due to Covid-19 pandemic interviews were conducted over phone at the convenience of the respondents.

Data were summarized and analyzed through thematic analysis. Interviews were conducted with personnel from four relief organizations and from literature review. Information collected from literature review and interviews were used to examine and create a framework which suggests that sustainable DSCM needs to focus on few factors such as organizational capabilities, communication among partners, inventory management process, government and local authority support which eventually led to transparent, efficient and effective SCM process. A good fit among all these dimensions lead to create a sustainable DSCM process. 
Table 1 presents the four case organizations of our sample, which have Bangladesh based offices. For confidentiality reasons, and due to the sensitivity of the topic, we offered the participants anonymity.

Table 1: Key information of case study organizations

\begin{tabular}{|c|c|c|c|c|}
\hline Name & Organization A & Organization B & Organization $\mathrm{C}$ & Organization D \\
\hline $\begin{array}{l}\text { Yearly } \\
\text { budget }\end{array}$ & $\begin{array}{l}\text { BDT } 1280.28 \\
\text { million (year of } \\
2020 \text { ) }\end{array}$ & $\begin{array}{l}\text {-\$437 million (in } \\
2020) \\
\text {-\$46 million for } \\
\text { Covid-19 pandemic. }\end{array}$ & $\begin{array}{l}\text {-\$321million } \\
\text { (Humanitarian- } \\
\$ 115 \text { million) } \\
-\$ 38 \text { million for } \\
\text { Covid-19 } \\
\text { pandemic. }\end{array}$ & $\begin{array}{l}\text { Depend on donors } \\
\text { contribution }\end{array}$ \\
\hline $\begin{array}{l}\text { Numbers of } \\
\text { volunteers }\end{array}$ & $\begin{array}{ll}873,342( & 61 \% \\
\text { male an } & 39 \% \\
\text { female }) & \end{array}$ & $\begin{array}{l}300 \text { stuff and } 208 \\
\text { national colleagues }\end{array}$ & $\begin{array}{l}\text { Professional and } \\
\text { volunteers }\end{array}$ & $\begin{array}{l}40 \text { professionals } \\
\text { and thousands of } \\
\text { volunteers }\end{array}$ \\
\hline $\begin{array}{l}\text { Type of } \\
\text { activities } \\
\text { and aid }\end{array}$ & $\begin{array}{l}\text { Early warning } \\
\text { system, search \& } \\
\text { rescue, } \\
\text { evacuation, } \\
\text { sheltering, first } \\
\text { aid, relief } \\
\text { distribution and } \\
\text { rehabilitation } \\
\text { activities }\end{array}$ & $\begin{array}{lr}\begin{array}{l}\text { Disaster } \\
\text { preparedness }\end{array} & \text { and } \\
\text { response, } & \text { Relief } \\
\text { operations, } & \text { food, } \\
\text { shelter, } & \text { risk } \\
\text { reduction, } & \text { health } \\
\text { security, } & \text { child } \\
\text { protection, } & \text { site } \\
\text { management, pure } \\
\text { water, sanitation, } \\
\text { education. }\end{array}$ & $\begin{array}{l}\text { Food security, } \\
\text { environmental } \\
\text { resilience, } \\
\text { education, } \\
\text { democracy and } \\
\text { governance, } \\
\text { health service( } \\
399 \text { clinics and } \\
10700 \text { satellite } \\
\text { clinics), } \\
\text { humanitarian } \\
\text { assistance }\end{array}$ & $\begin{array}{l}\text { Free Library with } \\
7,000 \text { books, } 1 \mathrm{Tk} \\
\text { meals for street } \\
\text { kids, Orphanage, } \\
\text { Free Cloths or } \\
\text { teaching material } \\
\text { distribution. }\end{array}$ \\
\hline
\end{tabular}




\begin{tabular}{|c|c|c|c|c|}
\hline $\begin{array}{l}\text { Type of } \\
\text { activities } \\
\text { during } \\
\text { Covid-19 } \\
\text { pandemic }\end{array}$ & $\begin{array}{l}\text {-supplied } \\
\text { disinfection } \\
\text { spraying kits, } \\
\text { water } \\
\text { purification kit, } \\
\text { training for } \\
\text { staffs and } \\
\text { establishing } \\
\text { hand washing } \\
\text { station, clean } \\
\text { drinking water, } \\
\text { cooked food, } \\
\text { packaged foods } \\
\text { at all } 64 \text { district. }\end{array}$ & $\begin{array}{lr}\text { Providing } & \text { food } \\
\text { security, providing } \\
\text { support to farmers, } \\
\text { working } & \text { with } \\
\text { government } & \text { to } \\
\text { continue } & \text { food } \\
\text { production } & \text { to } \\
\text { maintain continuous } \\
\text { supply of food, } \\
\text { providing health } \\
\text { security to pregnant } \\
\text { women in pandemic, } \\
\text { providing distant } \\
\text { learning platform, } \\
\text { create awareness } \\
\text { about hygiene, } \\
\text { washing hands in } \\
\text { current pandemic. }\end{array}$ & $\begin{array}{l}\text { Helping to } \\
\text { strengthen } \\
\text { COVID-19 } \\
\text { testing capacity } \\
\text { of Bangladesh } \\
\text { laboratories; } \\
\text { improve the care } \\
\text { given to COVID- } \\
19 \text { patients; } \\
\text { control } \\
\text { the spread of the } \\
\text { infection; and } \\
\text { dispel myths and } \\
\text { misconceptions } \\
\text { about the } \\
\text { disease. }\end{array}$ & $\begin{array}{l}\text { The foundation } \\
\text { distributed food and } \\
\text { hygiene products to } \\
\text { the underprivileged } \\
\text { community during } \\
\text { this time. They also } \\
\text { distributed PPE for } \\
\text { the healthcare } \\
\text { professionals } \\
\text { working in the } \\
\text { coronavirus } \\
\text { treatment centers. } \\
\text { Other activities } \\
\text { included } \\
\text { disinfectant } \\
\text { spraying on the } \\
\text { streets, distributing } \\
\text { crops and } \\
\text { vegetables collected } \\
\text { from the farmers of } \\
\text { rural areas }\end{array}$ \\
\hline $\begin{array}{l}\text { Operating } \\
\text { time in the } \\
\text { country }\end{array}$ & $\begin{array}{l}47 \text { years (since } \\
1973)\end{array}$ & $\begin{array}{l}49 \text { years ( since } \\
1971)\end{array}$ & $\begin{array}{l}49 \text { years }(\text { since } \\
1971)\end{array}$ & 7 years (since 2013 ) \\
\hline $\begin{array}{l}\text { Attitude of } \\
\text { Government } \\
\text { towards the } \\
\text { organization }\end{array}$ & $\begin{array}{l}\text { Supportive and } \\
\text { act in partnership }\end{array}$ & $\begin{array}{l}\text { Supportive and act in } \\
\text { partnership }\end{array}$ & Supportive & Supportive \\
\hline
\end{tabular}

\section{Analyses}

Data was being analyzed by thematic analysis. The raw qualitative data was converted into theoretical interpretations. For this purpose, codes were identified initially from the interview 
questions and answers. These codes were divided into a few categories and finally into six themes. The themes were then analyzed to get the concluding remarks based on contents of each category. From findings of this study, it was evident that there were several factors required for the development of relief operations. The common themes were identified as organizational capabilities, communication among partners, inventory management process, government and local authority support, transparent SCM process and efficient \& effective SCM process. The following table contains the themes, categories, codes and references from NVivo 12 software.

Table 2: Themes and codes with references from NVivo 12 software

\begin{tabular}{|c|c|c|c|c|c|}
\hline $\begin{array}{l}\text { Themes( based on } \\
\text { RQ) }\end{array}$ & Categories & Name of codes & Files & $\begin{array}{l}\text { Refer } \\
\text { ences }\end{array}$ & $\begin{array}{l}\text { Percent } \\
\text { coverage } \\
\text { from } \\
\text { interview } \\
\text { answers }\end{array}$ \\
\hline \multirow{8}{*}{$\begin{array}{l}\text { Theme } \\
\text { organizational } \\
\text { capability and } \\
\text { sustainable DSCM }\end{array}$} & \multirow{4}{*}{$\begin{array}{l}\text { Organizational } \\
\text { resources }\end{array}$} & Internal resources & 1 & 21 & $11.71 \%$ \\
\hline & & Skilled HR & 1 & 15 & $7.37 \%$ \\
\hline & & Resource placement & 1 & 2 & $1.27 \%$ \\
\hline & & Existing technology & 1 & 13 & $6.65 \%$ \\
\hline & \multirow{4}{*}{$\begin{array}{l}\text { Organizational } \\
\text { capabilities }\end{array}$} & Technological support & 1 & 8 & $3.07 \%$ \\
\hline & & $\begin{array}{l}\text { Relationship with } \\
\text { partners }\end{array}$ & 1 & 1 & $0.73 \%$ \\
\hline & & SC transparency & 1 & 2 & $1.09 \%$ \\
\hline & & $\begin{array}{l}\text { Capability to Cope up } \\
\text { with changes }\end{array}$ & & & \\
\hline \multirow{8}{*}{$\begin{array}{l}\text { Theme } \\
\text { Communication } \\
\text { among partners } \\
\text { and } \\
\text { lransparency }\end{array}$} & \multirow{8}{*}{$\begin{array}{l}\text { Communication } \\
\text { and } \\
\text { Coordination }\end{array}$} & $\begin{array}{l}\text { Relation with other } \\
\text { partners }\end{array}$ & 1 & 1 & $0.17 \%$ \\
\hline & & $\begin{array}{l}\text { Relation with other } \\
\text { humanitarian } \\
\text { organizations }\end{array}$ & 1 & 2 & $0.56 \%$ \\
\hline & & Operational challenges & 1 & 1 & $0.22 \%$ \\
\hline & & Cost & 1 & 1 & $0.60 \%$ \\
\hline & & Transparent relationship & 1 & 8 & $3.22 \%$ \\
\hline & & Trust & 1 & 7 & $2.54 \%$ \\
\hline & & Product flow & 1 & 6 & $2.64 \%$ \\
\hline & & Information flow & 1 & 9 & $4.38 \%$ \\
\hline \multirow{7}{*}{$\begin{array}{l}\text { Theme } 3(\mathrm{SC} \\
\text { transparencies and } \\
\text { sustainable } \\
\text { DSCM) }\end{array}$} & \multirow{7}{*}{$\begin{array}{l}\text { Transparent } \\
\text { SCM }\end{array}$} & Information sharing & 1 & 17 & $10.41 \%$ \\
\hline & & Donor response & 1 & 9 & $6.17 \%$ \\
\hline & & Speed of service & 1 & 6 & $4.58 \%$ \\
\hline & & Operational costs & 1 & 2 & $1.16 \%$ \\
\hline & & Tracking & 1 & 2 & $0.75 \%$ \\
\hline & & Knowledge sharing & 1 & 4 & $2.08 \%$ \\
\hline & & Safety and security & 1 & 12 & $8.19 \%$ \\
\hline $\begin{array}{ll}\text { Theme } & 4 \\
\text { (Warehouse } & \&\end{array}$ & $\begin{array}{l}\text { Inventory } \\
\text { management }\end{array}$ & $\begin{array}{lr}\text { Warehouse } & \text { and } \\
\text { distribution } & \text { center }\end{array}$ & 1 & 5 & $3.50 \%$ \\
\hline
\end{tabular}




\begin{tabular}{|c|c|c|c|c|c|}
\hline \multirow{6}{*}{$\begin{array}{l}\text { inventory } \\
\text { management and } \\
\text { SC efficiency and } \\
\text { effectiveness) }\end{array}$} & & \multicolumn{4}{|l|}{ placement } \\
\hline & & $\begin{array}{l}\text { No. of warehouse and } \\
\text { distribution center }\end{array}$ & 1 & 4 & $2.89 \%$ \\
\hline & & Cost related to inventory & 1 & 10 & $6.25 \%$ \\
\hline & & Delivery time & 1 & 8 & $5.57 \%$ \\
\hline & & Procurement & 1 & 6 & $3.09 \%$ \\
\hline & & Service quality & 1 & 2 & $0.64 \%$ \\
\hline \multirow{6}{*}{$\begin{array}{l}\text { Theme 5 (local } \\
\text { authority and } \\
\text { government } \\
\text { support and } \mathrm{SC} \\
\text { efficiency and } \\
\text { effectiveness) }\end{array}$} & \multirow{4}{*}{$\begin{array}{l}\text { Local authority } \\
\text { support }\end{array}$} & Transportation service & 1 & 7 & $4.13 \%$ \\
\hline & & Voluntary service & 1 & 9 & $5.03 \%$ \\
\hline & & Community awareness & 1 & 3 & $1.61 \%$ \\
\hline & & $\begin{array}{ll}\text { Warehouse } & \text { and } \\
\text { distribution centers } & \end{array}$ & 1 & 5 & $3.73 \%$ \\
\hline & \multirow[t]{2}{*}{$\begin{array}{l}\text { Government } \\
\text { support }\end{array}$} & $\begin{array}{l}\text { Transportation } \\
\text { infrastructure }\end{array}$ & 1 & 14 & $8.17 \%$ \\
\hline & & Custom related issues & 1 & 8 & $4.03 \%$ \\
\hline \multirow{4}{*}{$\begin{array}{l}\text { Theme } 6 \quad \text { (SC } \\
\text { efficiency } \\
\text { effectiveness and } \\
\text { sustainable } \\
\begin{array}{l}\text { process) } \\
\text { pSCM }\end{array}\end{array}$} & \multirow[t]{3}{*}{ Efficiency } & Overall Cost & 1 & 9 & $7.47 \%$ \\
\hline & & Distribution service & 1 & 10 & $5.65 \%$ \\
\hline & & Inventory & 1 & 1 & $0.71 \%$ \\
\hline & Effectiveness & Quality & 1 & 7 & $2.36 \%$ \\
\hline
\end{tabular}

\section{Findings and discussions}

The common themes were identified as organizational capabilities, communication among partners, inventory management process, government and local authority support, transparent SCM process and efficient \& effective SCM process. The statements of the respondents were long and hence these were represented by codes. The codes were then grouped together to reveal six themes of this study.

The following subsections briefly describe qualitative interviews with propositions that were conducted to identify the factors required for a sustainable DSCM process.

\subsection{Organizational capabilities}

Organizational capabilities are important to maintain SC performance. Organizations capabilities are related to their resources like financial resources and other necessary stocks, skills, technologies and existing organizational processes. So how a company is using their resources, skills to adopt changes to cope up with their competitors, it is very important. This will ultimately lead to sustainable supply chain performance.

If organizations don't have sufficient resources, then they cannot deliver required material on time. Therefore, to handle any kind of emergencies and challenges, organizations need to have 
enough financial resources as well as materials in stock. A disaster is a sudden incident and to manage such kinds of challenges organizations must have full preparation.

Also, organizations must have required skills and technological back up to support their activities. Organizations also must contain skilled human resources to provide necessary service when required. Skilled manpower and advanced technologies are required to have efficient processes and provide required service on time.

Almost all interviewees concurred that to create sustainable DSCM process organizations must have adequate amount of resources, financial support, and technological support and infrastructure facilities. They must possess enough skilled resources to handle any challenges effectively and perform better than rivals. Thus a company can have a long lasting and sustainable SCM system.

The results from interview respondents also support the findings of Alem et al.(2016) who illustrated that organizational capabilities play a crucial role to overcome challenges related to relief operations in disaster areas and help to build up a sustainable DSCM process. According to Behl et al. (2019), technology is crucial to develop a resilient DSCM process though for developing countries it is challenging. Whereas organizational dynamic capabilities have significant impact to overcome any challenges and to create a sustainable DSCM process (Teece et al., 1997; Hong et al., 2018; Barreto, 2010). But according to Polater et al.(2020), dynamic capabilities cannot be successfully applied in the absence of appropriate operational processes, resources and SC strategies. Countries like Bangladesh do not have enough support in these areas (Shareef et al., 2019).

This leads to the first proposition as:

Proposition 1: The opportunities to lead a sustainable DSCM process are influenced by organizational resource availability and capabilities.

\subsection{Communication among partners}

Most of the respondents agreed that communication and coordination among SC partners play a vital role to create a transparent SCM process. Sufficient communication can build a relationship of trust among them. This will lead to sharing more information to ensure a smooth relief operation. Moreover better communication can be ensured by better network facilities. Thus a transparent SCM process can be developed. Moreover, by efficient information flow, the product flow will be smooth and on time delivery in required areas will be possible.

According to the interviewees' responses the relationship between communication among partners and SC transparency which will lead to create a sustainable DSCM process can be summarized in eight codes such as relation with other partners' humanitarian organizations, operational challenges, cost, transparent relationship, trust, product flow and information flow. 
Majority of the respondents agreed to the point that good coordination and communication among SC partners maximize information and product flows, promote trust and transparent relationships. Some of the respondents argued that operational challenges and cost can be minimized by effective communication and coordination in SC networks which eventually create a sustainable DSCM process.

The results of interviewees were supported by the literature of few authors as Dubey et al. (2019a), Alem et al. (2016) and Duran et al. (2011). They all agreed that communication and coordination among SC partners are key requirements for efficient information flow based on trust. Also it can reduce overall cost, help to build up a transparent SCM process and make a relief operation an effective one. This leads to the second proposition associated with communication among partners and transparency of SC as:

Proposition 2: The transparency in a supply chain system is directly influenced by the coordination and communication among partners.

\subsection{Transparent SCM process and sustainable DSCM process}

Proper communication and coordination among partners is a prior requirement for building a transparent SCM process. SC partners feel safe and secure to share information in a transparent system. Also in a transparent system the product flow can be easily tracked which eliminates the frequency of fraud activities and hence cost is minimized. In a transparent system also all partners work together on the basis of trust to create a sustainable system. Donors invest willingly in a transparent system as they can easily get the notification of how their investment is being used and how effectively relief is being distributed as per requirement. Hence by ensuring effective information, product and finance flow, a transparent system can help to create a sustainable DSCM process.

Interviewees' responses in terms of the relationship between transparent SCM process and sustainable DSCM process were summarized by a few codes such as information sharing, donor response, speed of service, operational costs, tracking, knowledge sharing, safety and security. Information sharing among SC partners was investigated as the most crucial factor in this regard based on interviewees response. Most of the interviewees also agreed that safety and security and donor response play important roles for building up a sustainable system. Number of interviewees also agreed that cost, service speed, knowledge sharing and product tracking is necessary for a sustainable DSCM process.

A portion of summarized results from interviewees match with Polater (2020), who found that effective communication is required to ensure a transparent system where product and information can flow smoothly. This subsequently reduces cost and helps to create a sustainable DSCM process. Some significant factors were revealed from the interviewees' responses such as donor response, problems in information sharing which was supported by Shareef et al. (2019) 
and hence these factors are crucial in Bangladesh context for creating a sustainable DSCM process. These arguments lead to the net proposition as:

Proposition 3: A transparent supply chain management system will lead to a sustainable DSCM process.

\subsection{Inventory management}

Majority of interviewees mentioned that inventory management has a significant impact on SC efficiency and effectiveness. Inventory stock can be effectively managed and utilized by proper location and number of distribution centers. Effective and efficient inventory management can enhance the probability of delivering required relief on time in disaster affected sites and thus lead time is reduced. Also, there must be an amount in stock to reduce the immediate purchasing cost with a high price. Thus material purchasing cost can be eliminated. The location of the warehouse also affects the delivery lead time which ultimately enhances delivery speed and enhances service quality. Thus SC efficiency and effectiveness can be increased.

As Interviewees' responses were in long statements, hence these were summarized by few codes such as warehouse and distribution center placement, no. of warehouse and distribution center, cost related to inventory, delivery time, procurement and service quality. Delivery time, costs and procurement policy were the crucial factors related to inventory management which can be challenging in the way to create sustainability according to interviewees' response. According to interviewees, the existing policy of stocking of relief items, warehouse locations and procurement are responsible for longer lead time to deliver the relief items. Also centralized procurement policy is accelerating the price.

These findings from respondents also support the findings of Alem et al (2016) who noted that warehouse location is very important for quick response. Also, warehouses must contain stock to fulfill the need of disaster victims to reduce purchasing cost (Bozkurt, 2011) and hence ensure an efficient and effective SC process. The above discussions lead to the fourth proposition as:

Proposition 4: Supply chain efficiency and effectiveness is impacted by effective inventory management in warehouse and distribution centers.

\subsection{Government and local authority support}

During interviews, a majority of the participants stated that the government must focus on improving transportation infrastructure because transportation is a crucial factor which affects delivery speed and ensures the smooth product flow. The distribution related challenges. Also the Government must consider the custom related issues, so that the relief items can cross the border without trouble. Thus all necessary relief materials can reach the site on time when 
required and reduce operation cost. In addition, local authority can also motivate people to get involved in voluntary work when required. Also they should work to create community awareness. Local authorities must help to build up more warehouses and distribution centers, to deliver the material when necessary. The coordinate service of government and local authority will enhance the possibility of creating an efficient and effective process.

According to the interviewees' responses the relationship between government and local authority support and sustainable DSCM can be summarized by six codes such as transportation service, voluntary service, community awareness, warehouse and distribution centers, transportation infrastructure and custom related issues. Interviewees' emphasis factors such as voluntary service, transportation infrastructure and custom related issues for sustainable DSCM process in Bangladesh. It was mentioned by respondents that distribution of relief items usually gets hampered for absence of proper transportation facility and budget. Moreover, there is shortage of human resources sometimes in the required areas that cause delay in the whole process. In Bangladesh, for the imported relief items, custom related issues should be flexible enough and the government should take care of this issue. For providing local volunteers local authorities can take initiative and provide proper training to create efficient manpower.

These results concurred with the statement of Filker et al. (2018) who revealed that unavoidable issues in poor transportation systems, custom related issues and late shipments are crucial to the DSCM process. Also Polater (2020) mentioned that government and local authority must work together to build an efficient and effective SC process. This leads to the fifth proposition as:

Proposition 5: Supply chain effectiveness and efficiency is influenced by local authority and government support.

\subsection{Efficient and effective SCM process and sustainable DSCM process}

During interviews, the majority of participants agreed that for there to be a sustainable DSCM process, the whole system must be efficient and effective and must be able to handle any emergency situation. For being efficient, the system must focus on reducing procurement and transportation costs as well as focus on quick distribution. An efficient and effective SCM process concentrates on cost reduction in terms of transportation cost, procurement cost, inventory cost as well as efficient distribution. Also effective processes focus on service quality. If the quality of service is good and ensures faster delivery, then the victims' needs can be fulfilled on time. In addition, some interviewees mentioned that an efficient process runs with minimum cost but gives optimum output and effective process focus on faster distribution. Thus, it can create a sustainable DSCM process.

Respondents highlighted a few issues for an efficient SCM process and creating a sustainable DSCM process which was summarized by four codes such as overall Cost, distribution service, 
inventory management and quality of service. Majority of the interviewees argued that minimizing overall cost, timely distribution process and service quality are vital issues in this regard in Bangladesh context.

The findings confirm Charles (2016) who pointed out that three factors including effectiveness, responsiveness and efficiency are important factors for disaster relief operations. This study further confirms findings of Duran et al. (2011) that SC efficiency and effectiveness can be developed by reducing operation cost as procurement and transportation cost and by reducing response time and hence create a sustainable DSCM process and these arguments lead to the sixth proposition as:

Proposition 6: Sustainable DSCM process is influenced by supply chain efficiency and effectiveness.

Combining all these insights from expert interviewees and existing literatures lead to a conceptual framework that link up the factors as organizational capabilities, communication among partners, inventory management process, government and local authority support which eventually lead to transparent, efficient and effective SCM process and finally to create a sustainable DSCM process. We believe that this work has made an adequate contribution by identifying factors, proposing the conceptual framework and formulating appropriate research propositions (Dwivedi et al., 2022b). The conceptual framework is shown in figure 1 in Appendix.

\section{Recommendations and managerial implications}

Based on results of the current study, it is suggested that the government of Bangladesh must take care of transportation facilities including transportation infrastructure, quality of roads, quality and quantity of vehicles which are very important for effective relief operations. The study also recommends that organizational capabilities, resources, human resources, in house skills, technological backup and infrastructure facilities are necessary to fulfill the need of disaster relief operations. If the organizations have enough capabilities and resources, there is scope to deliver materials on time by the help of efficient transportation facilities. Also organizations need to focus on more use of technologies like mobile applications, cloud based applications to maintain transparency and to maintain communication with local volunteers during relief operations.

The study also recommends that organizations must have sufficient financial support and materials to handle any kind of emergencies and challenges. A disaster is a sudden incident and to manage such kinds of challenges organizations must always have full preparation. Thus a company can have a long lasting and sustainable SCM system.

This study further recommended that communication and coordination among SC partners is equally important to build trust among SC partners. If there is trust, then partners feel safe to 
share information and hence relief flow will be smooth in such a process which will build a sustainable SCM process.

Effective inventory management is also recommended by this study to create a sustainable DSCM process. Proper inventory management can reduce operational cost including, procurement cost, transportation cost, product spoilage cost and unnecessary handling costs. Moreover, the number of warehouse and warehouse locations are vital factors for efficient inventory management. Hence it is recommended to establish warehouses near to disaster prone areas to deliver materials when needed.

Another important recommendation was regarding government and local authority support to create a sustainable system. Government support is recommended to create an efficient transportation system, provide necessary support in custom related issues. Also local authority support is recommended to create community awareness, help to engage potential volunteers in sites, also to build warehouses where necessary. The government and nongovernmental organizations should arrange necessary training to handle any emergency efficiently.

\section{Research implication}

The study provides theoretical knowledge regarding the factors creating a sustainable DSCM process for relief operations in Bangladesh. The study identified the factors which are crucial for creating a transparent and effective \& efficient system to create a sustainable DSCM system for relief operations in Bangladesh. Therefore, practically, Bangladesh humanitarian SCM agencies can get insights from this study, which factors need to be considered to create a sustainable DSCM process for relief operations.

\section{Conclusions}

Disaster supply chain management system of Bangladesh is working to handle any type of disaster efficiently and fulfill all necessary requirements of disaster affected areas. Nevertheless, more developed systems are required to overcome the existing shortage to handle any sort of disaster in future. Hence this study was conducted to sort out the factors needed to create a sustainable DSCM system for relief operations in Bangladesh. In this context, information was collected from four such organizations which participated directly in disaster related activities and some key areas were sorted to work on. These key areas were categorized in themes. Based on these themes, a conceptual framework was proposed in this study.

This study discusses the factors which are required to create an efficient and effective DSCM process that eventually helps to build up a sustainable system for relief operations in Bangladesh. Organizational capabilities, good communication among partners, proper inventory management, and transparency among SC partners, government and local authority support are 
crucial for efficient and effective DSCM process. Organizational capability is an important factor. Internal resources, skilled employees and existing technologies have remarkable impact on a sustainable system. Communication among SC partners creates trust among them and accelerates the scope of information sharing. This can ensure smooth product flow and eventually reduce operational cost. Donors are vital for the DSCM system. If a system is transparent, then donors can easily trace the flow of their investments and get interested to invest more. Also a transparent system is safe and secured. For managing relief operations, there must be dedicated warehouses. Location and number of warehouses impact on the flow of relief items. Hence location and quantity of warehouse must be carefully selected. In all areas of DSCM, government support can enhance the efficiency of the system. Transportation infrastructure is very poor in Bangladesh which hampers product distribution on time. Also, importing relief items, frequently get delayed due to long processes of customs. Government initiative in these issues can solve the problem and fasten the whole process. Local authority support is necessary to create an efficient SC process. By focusing on these factors, the anomalies in a system like fraud activities can be reduced, quality of service can be enhanced, operational costs can be reduced and quick delivery can be ensured which consequently will build up a sustainable DSCM process for relief operations.

\section{Limitations and guidelines for future research}

This study used thematic analysis. All the interview respondents were involved in humanitarian activities in different humanitarian organizations in Bangladesh and the number of respondents was limited to twenty who were selected randomly from four organizations. To create a sustainable disaster SCM for relief operations factors like organizational capabilities, communication among partners, inventory management and government and local authority support was considered as predominant factors in Bangladesh context to generalize the developing country contexts and other factors such as organizational dynamic capabilities were not considered. Hence, this study is only limited in Bangladesh context therefore the similar study can be extended for other developing country contexts and can evaluate the similarities or differences among various developing countries considering other factors.

Also there is paucity of research in this area for developing countries. The study collected data and analyzed data based on interview responses. Therefore, for further humanitarian research, the model of this study can be used for quantitative research and the hypotheses can be tested empirically to get more acute findings.

\section{Reference}

Ab Aziz, N. S., Kasmani, R. M., Samsudin, M. D. M., \& Ahmad, A. (2019), "Comparative analysis on semi-empirical models of jet fire for radiant heat estimation”, Process Integration and Optimization for Sustainability, Vol.3 No.3, pp. 285-305. 
Alem, D., Clark, A., \& Moreno, A. (2016), "Stochastic network models for logistics planning in disaster relief”, European Journal of Operational Research, Vol.255 No.1,pp.187-206.

Alinaghian, L., Qiu, J. and Razmdoost, K. (2021), "The role of network structural properties in supply chain sustainability: a systematic literature review and agenda for future research", Supply Chain Management, Vol. 26 No. 2, pp. 192-211.

Apte, A. (2010), "Humanitarian logistics: A new field of research and action", Technology, Information and Operations Management, Vol.3 No.1, pp.1-100.

Banomyong, R., Julagasigorn, P., Varadejsatitwong, P. and Piboonrungroj, P. (2019), "The Humanitarian Supply Chain Assessment Tool (HumSCAT)", Journal of Humanitarian Logistics and Supply Chain Management, Vol. 9 No. 2, pp. 221-249.

Barreto, I. (2010), "Dynamic capabilities: A review of past research and an agenda for the future", Journal of Management, Vol.36 No.1, pp.256-280.

BDRCS (2020), "Disaster risk management strategy", BDRCS, available at: http://www.bdrcs.org/disaster-risk-management-drm-strategy (accessed 14 November 2020).

Beamon, B.M. and Kotleba, S.A. (2006), "Inventory management support systems for emergency humanitarian relief operations in South Sudan", The International Journal of Logistics Management, Vol. 17 No. 2, pp. 187-212.

Beamon, B.M. and Balcik, B. (2008), "Performance measurement in humanitarian relief chains", International Journal of Public Sector Management, Vol. 21 No. 1, pp. 4-25.

Behl,A.and Dutta, P. (2018), "Humanitarian supply chain management: a thematic literature review and future directions of research", Annals of Operations Research, Vol. 283, pp. 10011044, doi: 10.1007/s10479-018-2806-2.

Biswal, A. K., Jenamani, M., \& Kumar, S. K. (2018), "Warehouse efficiency improvement using RFID in a humanitarian supply chain: Implications for Indian food security system", Transportation Research Part E: Logistics and Transportation Review, Vol.109, pp.205224.

Botchie, D., Damoah, I. S., \& Tingbani, I. (2021), "From preparedness to coordination: operational excellence in post-disaster supply chain management in Africa", Production Planning \& Control, Vol. No. 1, pp. 1-18.

Bozkurt, M. (2011), "The effects of natural disaster trends on the pre-positioning implementation in humanitarian logistics networks", available at: https://hdl.handle.net/11511/20619 (accessed 14 November 2020) 
Campbell, A. M., \& Jones, P. C. (2011), "Prepositioning supplies in preparation for disasters”, European Journal of Operational Research, Vol. 209 No.2, pp.156-165.

Carroll, A. and Neu, J. (2009), "Volatility, unpredictability and asymmetry: An organizing framework for humanitarian logistics operations?", Management Research News, Vol. 32 No. 11, pp. 1024-1037.

Chari, F., Ngcamu, B.S. and Novukela, C. (2021), "Supply chain risks in humanitarian relief operations: a case of Cyclone Idai relief efforts in Zimbabwe", Journal of Humanitarian Logistics and Supply Chain Management, Vol. 11 No. 1, pp. 29-45.

Charles, A., Lauras, M., Van Wassenhove, L. N., \& Dupont, L. (2016), "Designing an efficient humanitarian supply network", Journal of Operations Management, Vol. 47,pp. 58-70.

Coleman, L. (2006), "Frequency of man-made disasters in the 20th century", Journal of Contingencies and Crisis Management, Vol.14 No.1, pp.3-11.

Damoah, I.S. (2021), "Exploring critical success factors (CSFs) of humanitarian supply chain management (HSCM) in flood disaster management (FDM)", Journal of Humanitarian Logistics and Supply Chain Management, Vol. ahead-of-print No. ahead-of-print. https://doi.org/10.1108/JHLSCM-01-2021-0003.

Dashtpeyma, M., \& Ghodsi, R. (2021), "Humanitarian relief chain agility: identification and evaluation of enabling factors", International Journal of Emergency Services, https://doi.org/10.1108/IJES-12-2020-0069.

Day, J. G., Thomas, N. J., Achilles-Day, U. E., \& Leakey, R. J. (2012), "Early detection of protozoan grazers in algal biofuel cultures", Bio resource technology,Vol.114, pp.715-719.

De Leeuw, S., Vis, I. F., \& Jonkman, S. N. (2012), "Exploring logistics aspects of flood emergency measures", Journal of Contingencies and Crisis Management, Vol.20 No.3, pp.166179.

Disaster Management Bureau (2015), "National plan for disaster management, standing orders on disaster", Government of the People's Republic of Bangladesh, available at: http://modmr.portal.gov.bd (accessed 6 January 2021).

Dubey, R., Gunasekaran, A., Bryde, D. J., Dwivedi, Y. K., \& Papadopoulos, T. (2020), "Blockchain technology for enhancing swift-trust, collaboration and resilience within a humanitarian supply chain setting", International Journal of Production Research, Vol. 58 No.11,pp. 3381-3398.

Dubey, R., Altay, N. and Blome, C. (2019a), "Swift trust and commitment: the missing links for humanitarian supply chain coordination?", Annals of Operations Research, Vol. 283, pp. 159177, doi: 10.1007/s10479-017-2676-z. 
Dubey, R., Gunasekaran, A. and Childe, S.J. (2019b), "Big data analytics capability in supply chain agility", Management Decision, Vol. 57 No. 8, pp. 2092-2112, doi: 10.1108/MD-01-20180119 .

Dubey, R., Gunasekaran, A., Childe, S.J., Roubaud, D., Fosso Wamba, S., Giannakis, M. and Foropon, C. (2019c), "Big data analytics and organizational culture as complements to swift trust and collaborative performance in the humanitarian supply chain", International Journal ofProduction Economics, Vol. 210, pp. 120-136, doi: 10.1016/j.ijpe.2019.01.023.

Dubey, R. and Gunasekaran, A. (2016a), "The sustainable humanitarian supply chain design: agility, adaptability, and alignment", International Journal of Logistics Research and Applications, Vol. 19 No. 1, pp. 62-82.

Dubey, R., Gunasekaran, A., Altay, N., Childe, S.J. and Papadopoulos, T. (2016b), "Understanding employee turnover in humanitarian organizations", Industrial and Commercial Training, Vol. 48 No. 4, pp. 208-214.

Duran, S., Gutierrez, M. A., \& Keskinocak, P. (2011), "Pre-positioning of emergency items for CARE international”, Informs journal on applied analytics,Vol.41 No.3, pp.223-237.

Dwivedi, Y. K., Hughes, L., Kar, A. K., Baabdullah, A. M., Grover, P., Abbas, R., ... \& Wade, M. (2022a), "Climate change and COP26: Are digital technologies and information management part of the problem or the solution? An editorial reflection and call to action", International Journal of Information Management, Vol. 63, pp. 102456.

Dwivedi, Y. K., Hughes, L., Cheung, C. M., Conboy, K., Duan, Y., Dubey, R., ... \& Viglia, G. (2022b), "How to develop a quality research article and avoid a journal desk rejection", International Journal of Information Management, Vol. 63, pp. 102456.

Dwivedi, Y. K., Shareef, M. A., Mukerji, B., Rana, N. P., \& Kapoor, K. K. (2018), "Involvement in emergency supply chain for disaster management: a cognitive dissonance perspective", International Journal of Production Research, Vol.56 No. 21, pp. 6758-6773, https://doi.org/10.1080/00207543.2017.1378958

Ergun, O., Keskinocak, P., \& Swann, J. (2007), "Humanitarian Relief Logistics-Research center at Georgia Tech aims to have a positive impact on the world by improving the multi-billion dollar humanitarian relief sector", OR MS Today,Vol.34 No.6, pp.28.

Fikar, C., Hirsch, P. and Nolz, P.C. (2018), "Agent-based simulation optimization for dynamic disaster relief distribution", Central European Journal of Operations Research, Vol. 26, pp. 423442 .

Haque, C. E., \& Uddin, M. S. (2013), "Disaster management discourse in Bangladesh: a shift from post-event response to the preparedness and mitigation approach through institutional 
partnerships", In Approaches to Disaster Management-Examining the Implications of Hazards, Emergencies and Disasters, IntechOpen, available at: http://dx.doi.org/10.5772/54973, DOI: $10.5772 / 54973$.

Harrison, H., Birks, M., Franklin, R., \& Mills, J. (2017, January), "Case study research: Foundations and methodological orientations", In Forum Qualitative Sozialforschung/Forum: Qualitative Social Research, Vol. 18 No.1, https://doi.org/10.17169/fqs-18.1.2655.

He, Y., Zamani, E. D., Lloyd, S., \& Luo, C. (2022), “Agile incident response (AIR): Improving the incident response process in healthcare", International Journal of Information Management, Vol. 62, pp. 102435.

Holguín-Veras, J., Jaller, M., Van Wassenhove, L. N., Pérez, N., \& Wachtendorf, T. (2012), “On the unique features of post-disaster humanitarian logistics", Journal of Operations Management, Vol. 30, pp. 494-506.

Hollweck, T. (2015), "Robert K. Yin.(2014), "Case Study Research Design and Methods", Thousand Oaks, CA: Sage, Canadian Journal of Program Evaluation, Vol.30 No.1, pp. 282 pages.

Hong, J., Zhang, Y. and Ding, M. (2018), "Sustainable supply chain management practices, supply chain dynamic capabilities, and enterprise performance", Journal of Cleaner Production, Vol. 172, pp. 3508-3519.

Hossain, M. A. (2012), "Community participation in disaster management: role of social work to enhance participation”, Antrocom Online Journal of Anthropology, Vol. 9 No.1, pp.159-171.

Ivanov, D. (2020), "Viable supply chain model: integrating agility, resilience and sustainability perspectives-lessons from and thinking beyond the COVID-19 pandemic", Annals of Operations Research, pp.1-21,doi: 10.1007/s10479-020-03640-6.

Kunz, N. and Reiner, G. (2012), "A meta-analysis of humanitarian logistics research", Journal of Humanitarian Logistics and Supply Chain Management, Vol. 2 No. 2, pp. 116-147.

Kavota, J. K., Kamdjoug, J. R. K., \& Wamba, S. F. (2020), "Social media and disaster management: Case of the north and south Kivu regions in the Democratic Republic of the Congo", International Journal of Information Management, Vol. 52, pp. 102068.

Messina, D., Barros, A.C., Soares, A.L. and Matopoulos, A. (2020), "An information management approach for supply chain disruption recovery", The International Journal of Logistics Management, Vol. 31 No. 3, pp. 489-519.

Nagendra, N. P., Narayanamurthy, G., \& Moser, R. (2020), "Management of humanitarian relief operations using satellite big data analytics: The case of Kerala floods", Annals of Operations Research, pp.1-26. https://doi.org/10.1007/s10479-020-03593-w 
Negi, S., \& Negi, G. (2021), "Framework to manage humanitarian logistics in disaster relief supply chain management in India", International Journal of Emergency Services, Vol.10 No.1, pp. 40-76. https://doi.org/10.1108/JJES-02-2020-0005

Ozdemir, A.I., Erol, I., Ar, I.M., Peker, I., Asgary, A., Medeni, T.D. and Medeni, I.T. (2021), "The role of blockchain in reducing the impact of barriers to humanitarian supply chain management", The International Journal of Logistics Management, Vol. 32 No. 2, pp. 454-478.

Papadopoulos, T., Gunasekaran, A., Dubey, R., Altay, N., Childe, S. J., \& Fosso-Wamba, S. (2017), "The role of Big Data in explaining disaster resilience in supply chains for sustainability", Journal of Cleaner Production, Vol.142, pp.1108-1118.

Polater, A. (2021), "Dynamic capabilities in humanitarian supply chain management: a systematic literature review", Journal of Humanitarian Logistics and Supply Chain Management, Vol. 11 No. 1, pp. 46-80.

Relief web (2020), "Disaster Management Reference Handbook (2020) - Bangladesh", Relief web, available at: https://reliefweb.int/report/Bangladesh/ (accessed 6 November 2020).

Relief web (2020), "Humanitarian Coordination and Collaboration in Bangladesh, Relief web, available at: https://reliefweb.int/sites/reliefweb.int/files/resources/ (accessed 14 November 2020)

Ritchie,H.\& Roser, M.(2014),'Natural Disasters", Our World In Data, available at: https://ourworldindata.org/natural-disasters (accessed 7 November, 2020).

Roy, K. C., Hasan, S., Sadri, A. M., \& Cebrian, M. (2020), "Understanding the efficiency of social media based crisis communication during hurricane Sandy", International Journal of Information Management, Vol. 52, pp. 102060.

Schniederjans, D. G., Schniederjans, D. G., Ozpolat, K., Ozpolat, K., Chen, Y., \& Chen, Y. (2016), "Humanitarian supply chain use of cloud computing", Supply Chain Management: An International Journal, Vol.21 No.5, pp.569-588

Shah Alam Khan, M. (2008),"Disaster preparedness for sustainable development in Bangladesh", Disaster Prevention and Management, Vol. 17 No. 5, pp. 662-671.

Shareef, M. A., Dwivedi, Y. K., Kumar, V., Hughes, D. L., \& Raman, R. (2020), "Sustainable supply chain for disaster management: structural dynamics and disruptive risks", Annals of Operations Research, 0123456789. https://doi.org/10.1007/s10479-020-03708-3

Shareef, M. A., Dwivedi, Y. K., Mahmud, R., Wright, A., Rahman, M. M., Kizgin, H., \& Rana, N. P. (2019), "Disaster management in Bangladesh: developing an effective emergency supply chain network", Annals of Operations Research, Vol.283, pp.1463-1487. https://doi.org/10.1007/s10479-018-3081-y 
Sheu, J.B. (2007b), "An emergency logistics distribution approach for quick response to urgent relief demand in disasters", Transportation Research Part E, Vol.43 No. 6, pp.687-709.

Singh, R. K., Gupta, A., \& Gunasekaran, A. (2018), “Analysing the interaction of factors for resilient humanitarian supply chain", International Journal of Production Research, Vol. 56 No.21, pp.6809-6827.

Son, J., Lee, J., Oh, O., Lee, H. K., \& Woo, J. (2020), "Using a Heuristic-Systematic Model to assess the Twitter user profile's impact on disaster tweet credibility", International Journal of Information Management, Vol. 54, pp. 102176.

Sundarakani, B., Pereira, V. and Ishizaka, A. (2021),"Robust facility location decisions for resilient sustainable supply chain performance in the face of disruptions", The International Journal of Logistics Management, Vol. 32 No. 2, pp. 357-385.

Tanco, M., Escuder, M., Heckmann, G., Jurburg, D. and Velazquez, J. (2018), "Supply chain management in Latin America: current research and future directions", Supply Chain Management, Vol. 23 No. 5, pp. 412-430.

Tasnim Z.(2020), "Disruption in Global Food Supply Chain (FSCs) Due to Covid-19 Pandemic and Impact of Digitalization Through Block Chain Technology in FSCs Management", European Journal Of Business and Management,Vol.12 No. 7, pp.64-72.

Tatham, P., Loy, J., \& Peretti, U. (2015), "Three dimensional printing: A key tool for the humanitarian logistician?", Journal of Humanitarian Logistics and Supply Chain Management, Vol. 5 No.2, pp.188-208.

Tatham, P., Spens, K., \& Kovács, G. (2017), “The humanitarian common logistic operating picture: a solution to the inter-agency coordination challenge", Disasters, Vol.41 No.1, pp.77100.

Teece, D. J., Pisano, G., \& Shuen, A. (1997), "Dynamic capabilities and strategic management", Strategic Management Journal, Vol.18 No.7, pp.509-533.

Thomas, A. S., \& Kopczak, L. R. (2005), "From logistics to supply chain management: the path forward in the humanitarian sector", Fritz Institute, Vol.15 No.1, pp. 1-15.

Torabi, S. A., Shokr, I., Tofighi, S., \& Heydari, J. (2018), "Integrated relief pre-positioning and procurement planning in humanitarian supply chains", Transportation Research Part E: Logistics and Transportation Review, Vol. 113, pp.123-146.

UN (2015), "Disaster Risk Reduction in Everybody's Interest", United Nations,available at: www.un.org / press / iha1354/doc/htm (accessed 6 January 2021). 
U.S. embassy (2020), "Bangladesh Flood Victims to Receive Emergency Assistance from U.S. Government", U.S. Embassy Dhaka, available at: https://bd.usembassy.gov/bangladesh-floodvictims-to-receive-emergency-assistance-from-u-s-government ( accessed 5 August 2020).

U.S. embassy (2020), "U.S. Announces Humanitarian Assistance at the International Conference on Sustaining Support for the Rohingya Refugee Response", US embassy Bangladesh, available at: $\quad$ https://bd.usembassy.gov/u-s-announces-humanitarian-assistance-at-the-internationalconference-on-sustaining-support-for-the-rohingya-refugee-response-102220/ (accessed 14 November, 2020).

Van Wassenhove, L.N. (2006), "Humanitarian aid logistics: supply chain management in high gear", Journal of the Operational Research Society, Vol. 57 No. 5, pp.475-489.

Van Wassenhove, L. N., \& Pedraza Martinez, A. J. (2012), "Using OR to adapt supply chain management best practices to humanitarian logistics", International Transactions in Operational Research, Vol.19 No.(1-2), pp.307-322.

Whybark, D. C. (2007), "Issues in managing disaster relief inventories", International journal of production economics, Vol.108 No.(1-2), pp.228-235.

Winter, S. G. (2003), "Understanding dynamic capabilities", Strategic management journal, Vol.24 No.10, pp.991-995.

Yuan, F., Li, M., Liu, R., Zhai, W., \& Qi, B. (2021), "Social media for enhanced understanding of disaster resilience during Hurricane Florence", International Journal of Information Management, Vol. 57, pp. 102289.

Yu, W., Jacobs, M.A., Chavez, R. and Yang, J. (2019), "Dynamism, disruption orientation, and resilience in the supply chain and the impacts on financial performance: a dynamic capabilities perspective", International Journal of Production Economics, Vol. 218, pp. 352-362.

Zokaee, M., Tavakkoli-Moghaddam, R., \& Rahimi, Y. (2021), "A Hybrid Approach to a PostDisaster Reconstruction Supply Chain: Empirical Optimization Study", Automation in Construction, Vol. 129, 103811, https://doi.org/10.1016/j.autcon.2021.103811 


\section{Appendix}

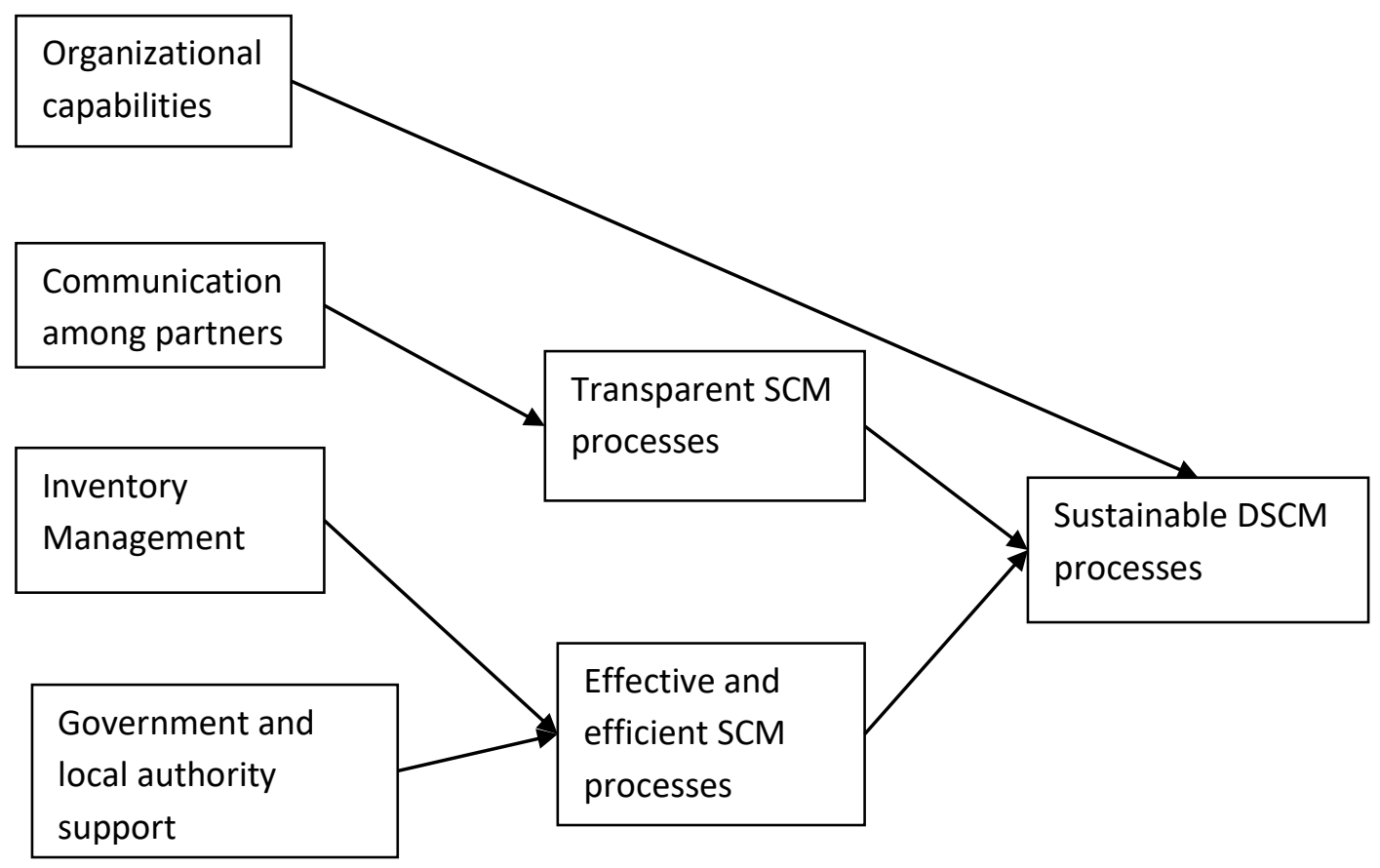

Figure 1: Theoretical framework for sustainable disaster supply chain management (SDSCM)

\section{Interview questions}

1. How do you maintain coordination among all partners in your supply chain?

2. Do you provide necessary training to groom up your employees?

3. Are the volunteers in areas technically skilled to exchange necessary information on time and handle any crisis situation? What you do to train them?

4. Do you consider the long term requirements of people? Mention few activities o support your answer.

5. Do you check the availability and quality of locally produced goods that will be used for relief operations? 
6. Did you face any problem while importing goods or machineries due to government policies and rules?

7. What type of formalities you maintain in custom offices to maintain a smooth custom clearance?

8. Which type of goods you prefer to purchase locally and which one you prefer to import? In case of local purchase, why do you prefer local procurement?

9. Is your preference of local purchasing affecting country's local economy?

10. In case of any emergency do you get enough cooperation from government related to custom issues and logistics support? 